\title{
Supported Peptide for Asymmetric a-Oxyamination of Aldehydes
}

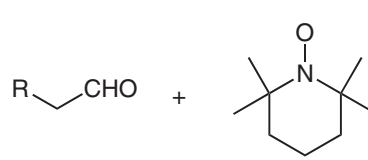

$1(20 \mathrm{~mol} \%)$ $\mathrm{FeCl}_{2} \cdot 4 \mathrm{H}_{2} \mathrm{O}(30 \mathrm{~mol} \%)$ $\mathrm{NaNO}_{2}(30 \mathrm{~mol} \%)$ air $\longrightarrow \mathrm{NaBH}_{4}$ THF- $\mathrm{H}_{2} \mathrm{O}(1: 2)$, r.t., $1 \mathrm{~h}$

(4 equiv)

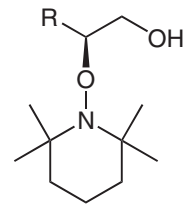

up to $87 \%$ yield up to $93 \%$ ee

Peptide catalyst 1:

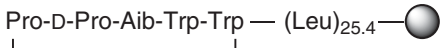

catalytically active site hydrophobic chain
$-\mathrm{O}=-\mathrm{HN}-\mathrm{CH}_{2}-\mathrm{CH}_{2}-\mathrm{PEG}-\mathrm{PS}$

amphiphilic resin<smiles>CC1(C)CCCC(C)(C)N1O[C@@H](CO)Cc1ccccc1</smiles>

a

$75 \%$ yield, $93 \%$ ee<smiles>CC1(C)CCCC(C)(C)N1O[C@@H](CO)CCCc1ccccc1</smiles>

$73 \%$ yield, $87 \%$ ee

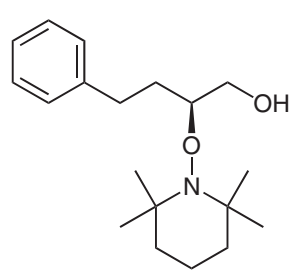<smiles>COc1ccc(CC[C@@H](CO)ON2C(C)(C)CCCC2(C)C)cc1</smiles>

d

$84 \%$ yield, $88 \%$ ee

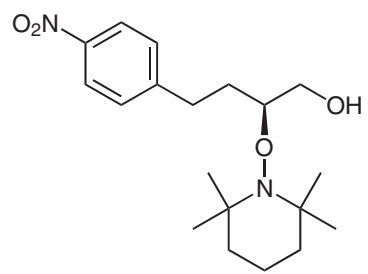

$76 \%$ yield, $87 \%$ ee
Significance: A polystyrene-poly(ethylene glycol) resin supported peptide catalyst bearing terminal five-residue Pro-D-Pro-Aib-Trp-Trp combined with polyleucine was prepared. The polymeric peptide was successfully applied to the asymmetric $\alpha$-oxyamination of aldehydes with TEMPO in the presence of a catalytic amount of $\mathrm{FeCl}_{2}$ and $\mathrm{NaNO}_{2}$ to give the corresponding products under aqueous aerobic conditions with up to $87 \%$ yield and $93 \%$ ee (5 examples).
Comment: The Kudo group has previously reported asymmetric hydrogenation (K. Akagawa et al. Tetrahedron: Asymmetry 2009, 20, 461; K. Akagawa et al. Org. Lett. 2008, 10, 2035) and asymmetric Friedel-Crafts alkylation (K. Akagawa et al. Tetrahedron Lett. 2009, 50, 5602) in aqueous media with this catalyst. The polyleucine moiety between the tryptophan and the resin support not only provides a hydrophobic environment, but also effects the stereoselectivity of the reaction.

SYNFACTS Contributors: Yasuhiro Uozumi, Haifeng Zhou 